\title{
220 ステンレス薄膜加熱を利用した赤外線サーモグラフィ法 Infrared Thermography with Stainless Film Heater
}

\author{
正 小笠原 永久， $\bigcirc$ 植木 陽子，正 千葉 矩正（防衛大）， \\ Nagahisa Ogasawara, Yoko Ueki and Norimasa Chiba \\ National Defense Academy, 1-10-20 Hashirimizu, Yokosuka 239-8686
}

\begin{abstract}
There are two reasons why IR-thermography, as a nondestructive inspection method, can't work well for non-painted metal; It is difficult to measure a temperature of a low emissivity surface by IR-thermography device. In addition, radiant energy is hardly absorbed in such a surface. For solving these two problems, the surface of the target should have been painted with black ink which has high emissivity. But this method is hard to apply during operation. In this report, we proposed a new active-thermography method with a thin stainless film. The film is painted with black ink for giving higher emissivity and it can heat the specimen surface uniformly by Joule energy. On the other hand, because the film is very thin, the target temperature appears on the surface of the stainless film, which can be observed by IR-thermography. The flaw size and depth can be identified from two data, temperature difference and phase difference between the flaw and normal area. It was confirmed that FEM simulation results are similar to experimental results for flat-bottomed holes.
\end{abstract}

Key Words: Thermography, Non-destructive inspection, Emissivity, Joule energy, Black body.

\section{1. 緒 言}

原子力発電所の配管や飛行機の翼などに発生する減肉欠 宿に対する非破壊検査は，主として専門技師による打音検 查や，超音波検査により実施されている。しかし，いずれ も技術の熟練が必要であり，また広範讲を同時期に検査で きないという問題点がある。一方，赤外線サーモグラフィ 法は，これら手法と比較して，広範囲を一度に効率よく検 查できる利点を持つが，対象物表面の金属光沢により物体 の表面温度が測定できない欠点を有する。

本研究では，従来の赤外線サーモグラフィ法では検査で きなかった低放射率構造体の減肉欠陥検知法を開発するこ とを目的とする。

\section{2. 薄膜加熟による赤外線サーモグラフィ法}

大型プラントの配管や飛行機の翼等の外表面は，未塗装 のままか，あるいは白色に近い塗装が施してある場合が多 い。つまり反射率が高く，放射率が非常に低い。これらに 熱放射によるアクティブサーモグラフィ法を適用した場合， 流入する放射エネルギ一量が低くなり効果的な加熱は難し く，また周辺熱源の反射の影響で，表面の温度を正確に捉 えることができない，研究室レベルでは，試験片表面に黒 色塗料を塗布し擬似黒体化することで上記問題を解決する が，実用レベルでは困難な場合もあり得る。

そこで，ステンレス薄膜を対象物表面に敷く方法を考え た，薄いステンレス薄膜は，電気抵抗が非常に高く，通電 すると均一に分布する大きな電気抵抗熱を発生する。この 加熱方法は，応答が非常に速く制御しやすい特長を有する. 発生した熱は対象物内に伝達し，内部欠陷の有無による熱 容量の差から不均一な温度分布を生じせしめる。 ステンレ ス薄膜は非常に薄いため, 対象物の異常温度分布を薄膜自 身の表面に再現できる。あらかじめステンレス薄膜を擬似 黒体化しておけば，赤外線サーモグラフィで表面温度分布 を測定でき，欠陷を検知できる。電気的に外部加熱するこ とから，通電を止めた後の冷却時だけではなく，通電加熱 時にも温度変化を観察することができる，本手法の概略図 を Fig. 1 に示す.

長さ $225 \mathrm{~mm}$, 横幅 $100 \mathrm{~mm}$, 䈃厚 $0.01 \mathrm{~mm}$ のステンレス薄 膜に 9A の電流を流した際の温度履歴を Fig. 2 に示す. 数 秒間で安定した温度を示し, 場所による温度差も少ないこ とが分かる.また通電終了後には, 十数秒で放熱し終え, 気温とほぼ同じ温度になっている。

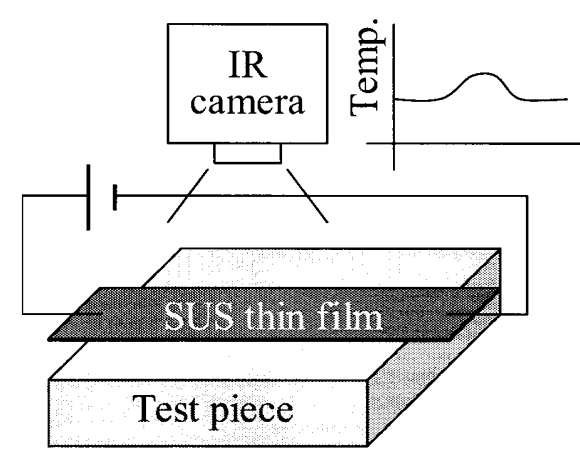

Fig. 1 Schematic of thin film thermography

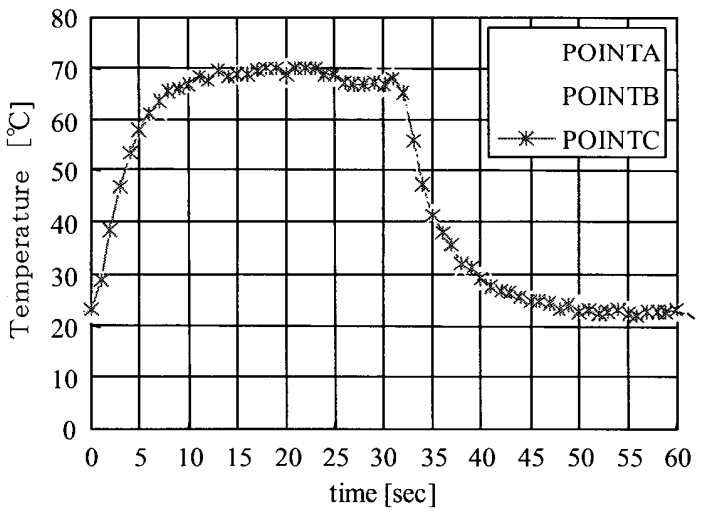

Fig. 2 Temperature of film surface vs. time

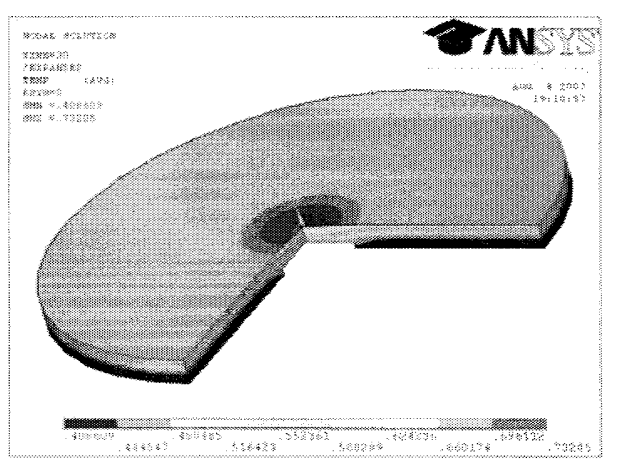

Fig. 3 FEM result of flat-bottomed hole model 


\section{3. 実験と有限要素法解析}

半径 $20 \mathrm{~mm}$, 深さ $2.5 \sim 7.5 \mathrm{~mm}$ の平底穴欠陥を有するステ ンレス平板（板厚 $10 \mathrm{~mm}$ ）を対象に, 前節で示したステン レス薄膜ヒー夕を用いて久陷検知を行う。まず，実験と有 限要素法を用いて本手法の有効性を探った。

\section{1 有限要素法による数値実験}

有限要素法プログラムには ANSYS を用いた。軸対称要 素を使用し，ステンレス平板試験片とステンレス薄膜をモ デル化している，両者間には隙間はないと仮定し，界面の 節点は共有している。上下自由表面の境界条件は, 自然対 流熱伝達条件（熱伝達率 $10 \mathrm{~W} / \mathrm{m}^{2} \mathrm{~K}$ ）である。また加熱条件 として, 薄膜の電気抵抗 $(0.162 \Omega)$ と電流条件 $(9 \mathrm{~A})$ 加 ら計算した電力量を薄膜の面積で除し, 熱流束 $\left(720 \mathrm{~W} / \mathrm{m}^{2}\right)$ として与えた. Fig. 3 は有限要素法の結果の一例を軸対称 回転させ表示したものである。

\section{2 実倹}

有限要素法による数值実験では，ステンレス薄膜と試験 片の間には隙間がないと仮定したが，実際の実験では，両 者間には高い接触熱抵抗が生じ, 激しい温度損失が起きる. また, ステンレス薄膜が均一な熱を発生しても, 熱の伝達 は均一に行えない。

そこで, 霧吹きにより試験片上表面に水滴を薄く撒き, その上にステンレス薄膜を敷いた，両者間の薄い水膜が密 着性を増し温度損失が減少する。シリコングリスなど温度 伝導率の高い粘性物質を用いた方が温度損失は少ないと予 測されるが，ここでは実機への適用を考え，試験後に残す 影響が少ないと思われる水膜を利用した。

試験片とステンレス薄膜の間に小さな気泡が入ることが ある。通電加熱時には小さな温度斑として観察されるため 欠陥々間違わ妨よう注意が必要だが，冷却時には温度拡散 により赤外線画像から瞬時に消えてしまう。

Fig. 4 に 30 秒間通電加熱した直後の赤外線画像を示寸. 赤外線サーモグラフィ装置には，日本アビオニクス社製 TVS-8500を利用している.

\section{3 実験と有限要素法の比較}

深さ $5.0 \mathrm{~mm}$ の平底穴欠陥に対する試験について, 実験と 有限要素法の結果を比較した。

Fig. 5 は欠陷上部と健常部の温度履歴示寸。加熱終了 後の健常部の温度に約 $0.2 \mathrm{~K}$ の違いが見られるが,他はほぼ 同じ挙動を示しており，本有限要素モデルが実験を良く再 現できていることが示された。Fig. 6 沈欠陥上部と健常部 の温度差履歴である.

\section{4. 晟肉久宿同定}

前節の実験により，本手法で減肉久陥を検知できること は示された。 今後は, 得られた温度デー夕を利用して久宿 サイズを同定することを検討する。

試験者が調整できる入力因子としては, 薄膜加熱で与え る熱流束 (薄膜に与える電力量), 加熱時間, 試験片表面の 熱伝達条件（自然対流 or 強制対流）が考えられる。試験 結果として得ら机る出力因子は, 久陥上部と健常部の最大 温度差 $\mathrm{dT}$, 最大温度差を生じる遅れ時間（位相差） $\mathrm{dt}$ など がある。

前節で確立された有限要素法モデルを用いて，入力因子 を変えた数值実験を行い出力因子のデータベースを作成し た後, 入力因子, 出力因子, 久皕サイズの関係老導き出せ ば，逆解析手法を用いて減肉久陥の同定が可能となる。数 値実験結果の一例として, Fig. 7 亿熱流束量を変化させた 際の出力因子の变化を示した.

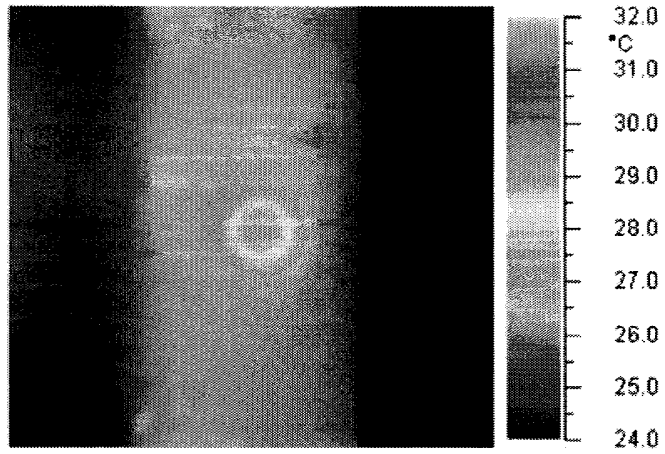

Fig. 4 Thermography of flat-bottomed hole specimen

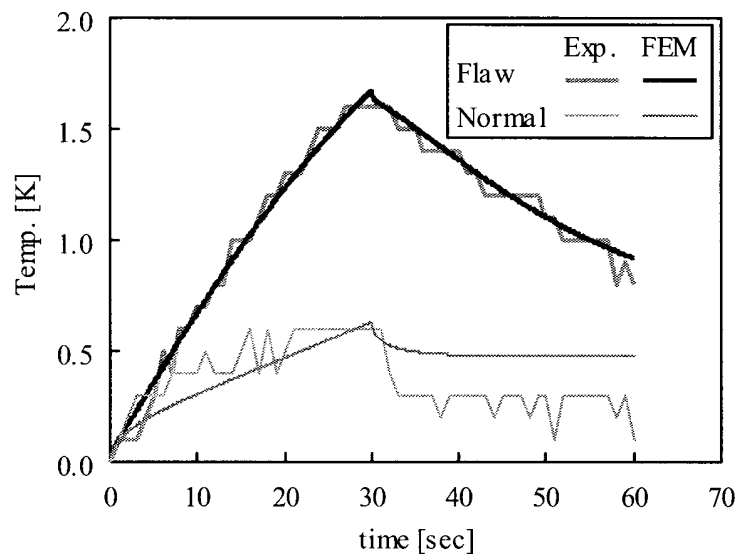

Fig. 5 Thermography of flat-bottomed hole specimen

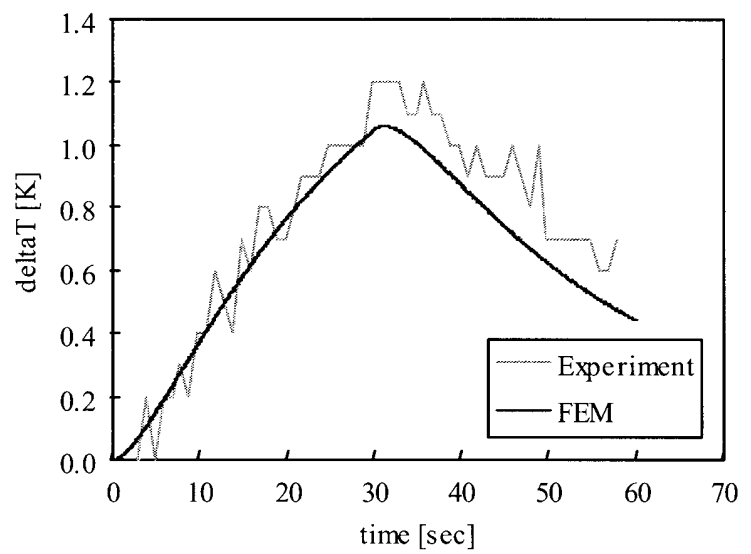

Fig. 6 Thermography of flat-bottomed hole specimen

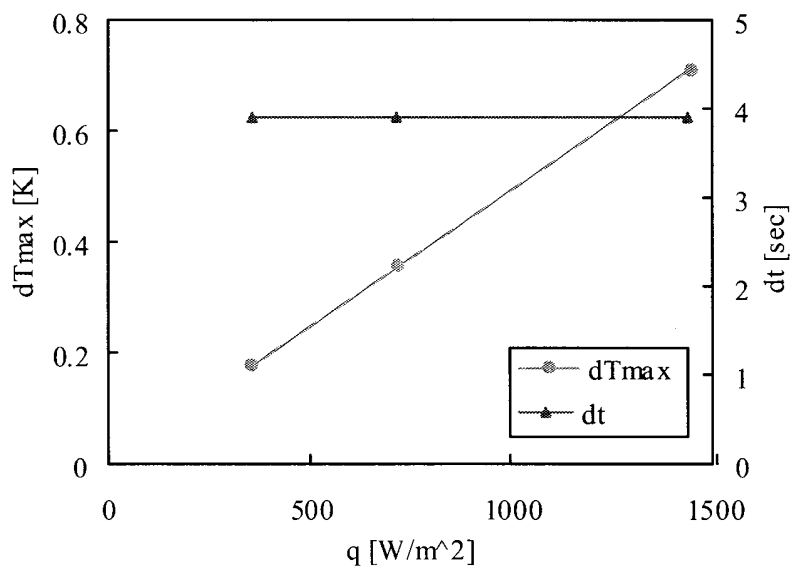

Fig. 7 heat flux vs. dT and time lag 